Saudi Journal of Business and Management Studies Abbreviated Key Title: Saudi J Bus Manag Stud ISSN 2415-6663 (Print) |ISSN 2415-6671 (Online) Scholars Middle East Publishers, Dubai, United Arab Emirates Journal homepage: https://saudijournals.com/sjbms

Original Research Article

\title{
The Mediating Role of Patient Satisfaction in the Relationship between Quality of Doctor Services and Patient Loyalty: Empirical Evidence from the Health Sector of Ghana
}

\author{
Antoinette Asabea Addo ${ }^{1 *}$, Weixin Wang ${ }^{2}$, Alex Boadi Dankyi ${ }^{3}$, Olivier Joseph Abban ${ }^{4}$, Geoffrey Bentum-Micah ${ }^{5}$ \\ ${ }^{1}$ Department of Public Administration, School of Management, Jiangsu University, No.301, Xuefu Road, Zhenjiang, Jiangsu Province, P. R. China \\ ${ }^{2,5}$ School of Management Jiangsu University, No.301, Xuefu Road, Zhenjiang, Jiangsu Province, P. R. China \\ ${ }^{3,4}$ School of Finance and Economics, Jiangsu University, No.301, Xuefu Road, Zhenjiang, Jiangsu Province, P. R.China
}

\begin{abstract}
DOI: $10.36348 /$ sjbms.2020.v05i02.007 $\quad$ | Received: 17.02 .2020 | Accepted: 24.02 .2020 | Published: 29.02 .2020
\end{abstract}
*Corresponding author: Antoinette Asabea Addo

\section{Abstract}

This study investigates the effect of the quality of doctor services on patient loyalty via the mediating influence of patient satisfaction. Variables like gender and proximity were also controlled for. Quantitative methods were used to analyze the data collected from a questionnaire that was randomly administered to out-patients (2500) in the five referral hospitals in Ghana. Results from the t-tests and ANOVA revealed that gender does not have an effect on patient satisfaction. Likewise, proximity did not have an effect on satisfaction and further loyalty. Correlation analysis results showed strong positive relationships between quality of doctor services and patient satisfaction, the quality of doctor services and patient loyalty and finally patient satisfaction and patient loyalty. This finding proves that the quality of services rendered by doctors influence the satisfaction of patients and further earns their loyalty.

Keywords: Service quality, doctor services, doctor's attitude, patient satisfaction, patient loyalty, health sector.

Copyright @ 2020: This is an open-access article distributed under the terms of the Creative Commons Attribution license which permits unrestricted use, distribution, and reproduction in any medium for non-commercial use (NonCommercial, or CC-BY-NC) provided the original author and source are credited.

\section{INTRODUCTION}

The medical field has undergone tremendous technological development, nonetheless, one thing remains dominant and that is the doctor-patient relationship. An effective doctor-patient relationship is "the heart and art of medicine"[1]. This relationship is an archetype of any expert-client relationship. Honavar [2] opines that a doctor or physician is responsible for diagnosing a patient's illness, recommending and obtaining informed consent for treatment and referring a patient to a specialist if need be. As the doctor performs his duties, there ought to be effective communication between the doctor and the patient[1], empathy[3], care and comfort and technical competence[4]. In the view of Krupat, Rosenkranz [5], a doctor who takes the patient-centered approach is likely to treat patients as partners and helps them make informed decisions. This facilitates the delivery of quality healthcare and leads to the liking of the doctor[6], understanding and adherence to treatment[7, 8], continuity of care[9], patient satisfaction and trust[10]. Additionally, this doctorpatient relationship is influenced by the congruence of beliefs between doctor and patient about control in their relationship as well as by one another's behavior[11]. Thus, in order to maintain this doctor-patient relationship, emphasis should be placed on a mutual understanding and agreement between doctor and patient[12].

Few studies on doctor or physician services are available [13-16]. Further, no studies have investigated how doctor services impact patient satisfaction and loyalty in Ghana. Hence, there is the need to explore the relationship among quality of doctor services, patient satisfaction and patient loyalty. Therefore, this study purports to provide an integrated model that explains the relationship among quality of doctor services, patient satisfaction, and patient loyalty. Next, the correlations among these constructs within the integrated model will be examined systematically. Finally, the mediating influence of patient satisfaction 
on the other two constructs (quality of doctor services and patient loyalty) will be examined.

\section{Theoretical development and research hypotheses Quality of Doctor Services}

No matter our ages, gender, education, socioeconomic status or cultural background, doctors play significant roles in our lives. They are the providers of the largest share of medical care in all countries. Doctors are mostly the first point of contact in the cases of provision of preventive and ongoing essential care [17, 18]. A medical doctor or simply doctor is a professional who practises medicine, which is concerned with the study, diagnosis, prognosis and treatment of disease, injury, and other physical and mental impairments in order to promote, maintain, or restore health[15]. Doctors play indispensable roles in the healthcare sector and in the community as a whole. They help patients prevent, understand, and manage illness. Also, they diagnose and treat diseases and injuries within the general population. Furthermore, they are involved in creating a good inter-personal relationship, providing and exchanging information and making treatment-related decisions[19, 20]. The doctor is expected to exhibit multidimensional qualities in the areas of assurance (assuring patients they will receive the best of care), empathy (showing genuine care and concern), reliability (being available and punctual), expertise (exhibiting technical competence) and tangibles (providing care in a friendly and clean environment)[21, 22].With all these things done, it ensures a higher likelihood that a patient will be satisfied.

\section{PATIENT SATISFACTION}

The concept of patient satisfaction is multifaceted; hence, there has not been a uniform definition for this construct. Farley, Enguidanos [23] referred to patient satisfaction as "patients' emotions, feelings and their perception of delivered healthcare services". Again, Kim, Cho [24] defined patient satisfaction as "the judgment of perceived value and sustained response toward service related stimulus before, during or after the consumption of medical services by a patient". Al-Abri and Al-Balushi [25] explained patient satisfaction as "a degree of congruency between patient expectations of ideal care and their perceptions of real care received". From their view, patient satisfaction is a critical indicator of quality and efficient healthcare services. The quality of healthcare delivery greatly affects patient satisfaction which tends to elicit positive patient behaviors such as loyalty, trust, commitment and others[26]. In view of this Lee, Chen [27] suggests that, healthcare providers ought to understand the patient's expectations and try to meet them.

Bjertnaes, Sjetne [28] in their study stated that the key predictors of inclusive patient satisfaction are the reported experiences of patients and the fulfilment of expectations. This simply means that satisfaction is a sum product of performance and expectations[29]. For over two decades, patient satisfaction surveys are being used as a yardstick to evaluate the healthcare delivery system. This is important because satisfied patients are more likely to follow the prescribed treatment plan, maintain the relationship with a specific health care provider, re use the services of the healthcare unit and recommend it to others[30, 31].

\section{PATIENT LOYALTY}

Patient loyalty is a complex construct affected by many variables, hence the lack of a standard definition. Some authors explain loyalty as an attitude[32], others define it in terms of intentions[33], and yet still others discuss it as a pattern of behavior[34]. Consumer loyalty is defined as "a deeply held commitment to rebuy or re patronize a preferred product or service consistently in the future, causing repetitive same-brand or same-brand-set purchasing, despite the potential for situational influences and marketing efforts to cause switching behavior"[35]. Chipidza, Wallwork [15]also explained patient loyalty as "the patient's willingness to forgive a doctor for any inconvenience or mistake". A loyal patient is indispensable to the development and or stability of a healthcare unit. But there are some factors which attract such loyalty and they include; trust, commitment, satisfaction, patient participation in the process of diagnosis and treatment decision-making, service quality and others[36-39]. A loyal patient is an asset to any organization, as they repurchase, spread positive words of mouth, recommend to others and show resistance to competitors[40, 41]. This in turn increases the profitability and the brand image of the healthcare unit.

\section{The relationship among doctor services, patient satisfaction and patient loyalty}

Studies over the years has established relation or possible relations amongst quality of doctor services, patient satisfaction and patient loyalty. This lies in the increasing competition among hospitals for sustainable growth whilst being mindful of patients' primary healthcare satisfaction.

There has been an increase in the need to improve quality and efficiency in healthcare delivery and one of the key determinants of quality of care is patient satisfaction[42]. Evidence shows that much patient satisfaction is due to a good doctor-patient relationship and vice versa. Doctor services account as the most important factor in explaining patient satisfaction[1, 43]. Research shows that patients were particularly satisfied with the qualities of doctors such as listening of complaints, explanation of their ailments, advice and treatment and their general behavior (empathy, respect, confidence, etc.). Therefore, Marcinowicz, Chlabicz [44] and Sodani, Kumar [45]suggest that doctors go the extra mile to ensure they 
give more attention and time to their patients and have quality interactions with them. In doing so, a healthy doctor-patient relationship will be established which will in turn enhance patient satisfaction. Thus, the first hypothesis is described as follows:

\section{H1: Doctor Services has a positive effect on patient satisfaction.}

Currently, service managers in the health sector are bent on establishing good relationships with patients and enhancing patient loyalty. Although, few literatures exist on doctor-patient relationship and or the relationship between doctor services and patient loyalty. In this era of competition, the patient's loyalty to a doctor(s) is relevant to medical services and doctor-patient relationship is fundamental[38, 46]. Recommends that hospitals provide patients the opportunity to be involved in the diagnosis and treatment decision making process together with their doctors or physicians. Research outcomes confirm that an effective doctor- patient relationship is positively influenced by the interaction behavior of service providers, thus doctors[36]. This behavior boosts the confidence of the patient and further increases the patient's loyalty to his doctor[47]. Patient experience, whether good or bad, predicts patient loyalty. If a patient's actual experience was better than their expectations, they become loyal and vice versa[48, 49]. Even in pharmacy services, the provision of specialized service correlated to increased patient loyalty to the particular pharmacy[50]. Some studies also revealed that physician's curing service quality and interpersonal service quality positively affected patients' loyalty[51, 52]. The second hypothesis is described as follows:

\section{H2: Doctor Services has a positive effect on patient loyalty.}

In the healthcare environment, several studies have examined the links between patient satisfaction and patient loyalty. Their results indicated that patient satisfaction has a significantly positive impact on patient loyalty [49, 53, 54]. For healthcare units, satisfied patients are important because they maintain the relationship with a specific healthcare provider, revisit the hospital and recommend it to others, thus, family and friends $[30,55]$. Additionally, a study on the relationship between patient satisfaction and re-visit intention(loyalty) confirmed that there is a significant effect of patient satisfaction on loyalty[24]. Thus, it is most likely that satisfied patients will be more loyal to their service provider or hospital. The third hypothesis is described as follow:
H3: Patient satisfaction has a positive effect on patient loyalty.

In most studies, satisfaction appears as either the antecedent or consequence of the variables under examination. Platonova, Kennedy [56] in their study on satisfaction, trust and loyalty found that satisfaction is a significant predictor of patients' intentions to stay with the doctor and to recommend the primary care provider to others. Kessler and Mylod [53] revealed that satisfaction affects propensity to return, thus, loyalty. To a large extent, satisfaction affects loyalty[31, 57]. On the contrary, a research found that satisfaction and perceived value has no significant impact on patient loyalty[37]. Researches prove that the behavior of a service provider can predict the satisfaction level of the consumer [58-60]. Likewise, effective interaction behaviors of doctors enhances patients' loyalty[47]. The fourth hypothesis is described as follow:

H4: Patient satisfaction mediates the relationship between doctor services and patient loyalty.

H5: Gender and proximity have an influence on patient satisfaction.

\section{METHODOLOGY}

This study uses the quantitative research approach as this approach allows the purpose of explanation, prediction and controlling of certain variables by way of helping the researcher answer questions about the relationship between the measured variables (quality of doctor services, patient satisfaction and patient loyalty). The study is empirical based on the primary data collected from outpatients in five (5) referral hospitals in Ghana. In total (2500) questionnaires were distributed and the respondents were selected using a simple random sampling method. A 20-item self-administered questionnaire was designed using existing instruments and information garnered from literature. Apart from the demographics, all the other items were measured on a 5-point Likert scale with responses ranging from $1=$ very satisfied, $2=$ satisfied, $3=$ neutral, $4=$ unsatisfied and $5=$ very unsatisfied.

The Cronbach Alpha coefficient was used for the reliability test and the reliability coefficient obtained was 0.898 . This denotes that the instrument is reliable because according to Cooper and Schindler [61], an instrument is reliable when the reliability coefficient of the instrument is above 0.70 . Therefore, the reliability of this instrument is acceptable. Consequently, we calculated the Cronbach's alpha coefficients of the various constructs measured as shown in Table 1 below.

Table-1: Reliability Statistics

\begin{tabular}{|r|r|r|}
\hline Description & Cronbach's Alpha & Number of items \\
\hline Quality of doctor services & 0.777 & 7 \\
\hline Patient satisfaction & 0.807 & 7 \\
\hline Patient loyalty & 0.692 & 2 \\
\hline Overall Questionnaire reliability & 0.898 & 16 \\
\hline
\end{tabular}


In order to observe the content validity, the questionnaire adopted had a clear structure and the questions raised were clearly and simply expressed, thereby eliminating any possibility of misinterpretations. Prior to the collection of data, a piloting test of the instrument on 100 patients who were not part of the main study were done. The outcome of the pretest helped in making definite amendments which ensured that the questions were simple and clear so that participants could fully understand. Before the administering the questionnaire, the following procedure was followed. Permissions were sought from the administrators of the hospitals. With the help of research assistants, the questionnaires were delivered to willing participants who were given the assurance that their responses will be used for only academic research. Patients who consented were literate and both physically and mentally sound. Out of the (2500) questionnaires distributed, the number of satisfactory completed questionnaires returned was (2360). Therefore, two thousand three hundred and sixty (2360) respondents were used for further statistical analysis. The results were analyzed using SPSS version 25 . The descriptive statistics (such as mean and standard deviation) were used to describe data in a summative form. Pearson product moment correlation coefficients were used to measure the relationship between variables (quality of doctor services and patient satisfaction) and the dependent variable (patient loyalty). The standard multiple regression analysis was also used to assess the relative contribution of the independent variables to the variability of the dependent variable. The Analysis of Variance (ANOVA) and t test were used to examine the mean demographic differences.

\section{RESULTS \\ Response rate}

The response rates of the questionnaires from the study participants were good. Out of the (2500) questionnaires distributed, the number of satisfactory completed questionnaires returned was (2360) which represents $94.4 \%$ response rate. Researchers postulate that high response rates, thus above $60-70 \%$ is ideal and ensures more accurate results $[62,63]$.

\section{Subjects}

The sample included 2360 outpatients. Table 2 shows the demographic data of the study sample. The demographic data about the respondents shows that 1163 (49.3\%) were males and 1197(50.7\%) were females.

Table-2: Demographics

\begin{tabular}{|r|r|r|}
\hline Variable (Gender) & Frequency & Percentage \\
\hline Males & 1163 & 49.3 \\
\hline Females & 1197 & 50.7 \\
\hline Total & 2360 & 100 \\
\hline
\end{tabular}

Summary descriptive statistics of the constructs

The data collected were analyzed to explore how patient loyalty is gained through the quality of doctor services with patient satisfaction playing a mediating role. The study is based on three (3) constructs; (a) quality of doctor services, (b) patient satisfaction and (c) patient loyalty. The overall mean for each construct was analyzed and are reported in Table 3.

Table-3: Summary Descriptive Statistics

\begin{tabular}{|r|r|r|r|}
\hline Item & Description & Mean & Std. Deviation \\
\hline 1 & Quality of doctor services & 2.6867 & 0.71413 \\
\hline 2 & Patient satisfaction & 3.1971 & 0.92232 \\
\hline 3 & Patient loyalty & 2.9191 & 1.08391 \\
\hline
\end{tabular}

Further our study assessed the mean differences of gender and proximity. Thus, we were interested in finding out if gender and proximity to a healthcare facility played any role in patients' satisfaction. The results are presented in table 4 .

Table-4: Gender and proximity mean differences

\begin{tabular}{|c|r|r|r|r|r|r|}
\hline \multirow{2}{*}{} & \multicolumn{7}{|c|}{ Test value = 0, 95\% confidence interval of the difference } \\
\cline { 2 - 7 } & \multicolumn{7}{|c|}{ T } & Df & Sig. (2 tailed) & Mean difference & lower & upper \\
\cline { 2 - 7 } & 2359 & 0.000 & 1.507 & 1.49 & 1.53 \\
Gender & 146.424 & 2359 & 0.000 & 1.501 & 1.48 & 1.52 \\
\hline
\end{tabular}

T test was used to test whether there was a significant difference in how males and females perceive patient satisfaction in relation to the quality of doctor services provided. It was hypothesized that gender will have an influence on patient satisfaction. This hypothesis was rejected based on the results in Table $4(\mathrm{df}=2359, \mathrm{t}=146.424, \mathrm{p}=0.000)$ since the $\mathrm{p}$ value is less than 0.05 , which proves that gender does not influence the concept of satisfaction. This is consistent with the findings of Bertakis and Azari [14] who found no significant gender differences in patient centered care between the male and female patients. However, the study by Qin, Boonme [64] found a significant effect of gender on the relationship between urgent care quality and patient satisfaction. Again, a t test was conducted to find out if proximity affects 
satisfaction and further, loyalty. This hypothesis was also rejected because the $\mathrm{p}$ value is less than $0.05(\mathrm{df}=$ $2359, \mathrm{t}=145.791, \mathrm{p}=0.000)$. Therefore, we conclude that proximity has no effect on satisfaction and further loyalty.

Table-5: ANOVA

\begin{tabular}{|rr|r|r|r|r|r|}
\hline & & Sum of squares & Df & Mean square & F & Sig. \\
\hline \multirow{4}{*}{ DS } & Between group & 0.025 & 1 & 0.025 & 0.049 & 0.825 \\
& Within group & 1203.022 & 2358 & 0.510 & & \\
& Total & 1203.046 & 2359 & & & \\
\hline \multirow{3}{*}{ PL } & Between group & 0.255 & 1 & 0.255 & 0.198 & 0.657 \\
& Within group & 3036.122 & 2358 & 1.288 & & \\
& Total & 30336.376 & 2359 & & & \\
\hline \multirow{2}{*}{ PS } & Between group & 0.003 & 1 & 0.003 & 0.004 & 0.950 \\
& Within group & 2054.070 & 2358 & 0.871 & & \\
& Total & 2054.074 & 2359 & & & \\
\hline
\end{tabular}

The study further decomposed the model assessing within and among group variations in the constructs to test whether proximity has significant effect on the different constructs (quality of doctor services, patient satisfaction and patient loyalty), an Analysis of Variance (ANOVA) test was conducted to test the hypothesis. The hypothesis [proximity has an effect on quality of doctor services (0.825), patient satisfaction (0.657) and patient loyalty (0.950) was accepted since $\mathrm{p}>0.05$, which proves that proximity has an effect on the variables measured.

Table-6: Correlation Analysis results:

\begin{tabular}{|r|r|r|r|r|}
\hline & & DS & PS & PL \\
\hline \multirow{4}{*}{ DS } & Pearson correlation & 1 & $0.722^{* *}$ & $0.591 * *$ \\
\cline { 2 - 5 } & Sig. (2 tailed) & & 0.000 & 0.000 \\
\cline { 2 - 5 } & $\mathrm{N}$ & 2360 & 2360 & 2360 \\
\hline \multirow{3}{*}{ PS } & Pearson correlation & $0.722^{* *}$ & 1 & $0.640^{* *}$ \\
\cline { 2 - 5 } & Sig. (2 tailed) & 0.000 & & 0.000 \\
\cline { 2 - 5 } & $\mathrm{N}$ & 2360 & 2360 & 2360 \\
\hline PL & Pearson correlation & $0.591 * *$ & $0.640 * *$ & 1 \\
\cline { 2 - 5 } & Sig. (2 tailed) & 0.000 & 0.000 & \\
\cline { 2 - 5 } & $\mathrm{N}$ & 2360 & 2360 & 2360 \\
\hline
\end{tabular}

Note: The strength and direction of the relationship between independent variables (quality of doctor services and patient satisfaction) and the dependent variable (patient loyalty).

In determining the strength and direction of the relationships, Pearson correlation analysis was used. Pearson's correlation coefficient (r) measures the strength of the association between two variables. The results of the study shows that the quality of doctor services had a significant positive effect on patient satisfaction $(r=0.722, p=0.000)$. This implies that the higher the quality of doctor services, the higher a patient's satisfaction becomes. Again, the quality of doctor services had a significant positive effect on patient loyalty $(r=0.591, p=0.000)$ which shows that the more the doctor renders qualified services, the more loyal a patient becomes. Further, the results $(r=0.640, p$ $=0.000$ ) indicated that patient's satisfaction has a significant positive effect on patient loyalty which proves that satisfaction tends to make patients more loyal.

Table-7: Regression Analysis Model summary

\begin{tabular}{|r|r|r|r|r|r|}
\hline Model & $\mathbf{R}$ & R Square & Adjusted R square & Std. error of the estimate & Durbin-Watson \\
\hline 1 & $0.867^{\mathrm{b}}$ & 0.844 & 0.794 & 0.84614 & 2.1 \\
\hline
\end{tabular}

The model indicates that $84.4 \%$ (RSquare $=0.844$ ) variation in patient loyalty is explained by two (2) predictor variables; quality of doctor services and patient satisfaction. The Durbin-Watson results indicates that the assumption of independent error is tenable since the figure for this data is 2.1 and is close to 2 [65]. 
Table-8: Coefficients

\begin{tabular}{|r|r|r|r|r|r|r|r|}
\hline Model & $\begin{array}{r}\text { Unstandardized } \\
\text { coefficient }\end{array}$ & & $\begin{array}{r}\text { Standardize } \\
\text { d coefficients }\end{array}$ & T & Sig. & $\begin{array}{r}\text { Collinearity } \\
\text { statistics }\end{array}$ & VIF \\
\hline & B & Std.Error & Beta & & & Tolerance & V \\
\hline $\begin{array}{r}\text { Model } \\
\text { constant) }\end{array}$ & 0.166 & 0.072 & & 2.320 & 0.020 & & \\
\hline PS & 0.543 & 0.027 & 0.447 & 20.130 & 0.000 & 0.478 & 2.090 \\
\hline DS & 0.425 & 0.035 & 0.268 & 12.064 & 0.000 & 0.478 & 2.090 \\
\hline
\end{tabular}

From the regression results presented in Table 8 , it can be noted that all the variables had a statistically significant effect on patient loyalty. Statistically significant effects were observed in patient satisfaction $(\mathrm{t}=20.130$, sig. $=0.000)$ and quality of doctor services $(\mathrm{t}=12.064$, sig. $=0.000)$. Patient satisfaction $(0.447)$ and quality of doctor services $(0.268)$ yielded positive Beta coefficients indicating that they result in patient loyalty. Therefore, at 0.05 significance level, the study concludes that doctor services have a positive effect on patient loyalty via patient satisfaction. Incidences of multi-collinearity were observed in the model since all of the variance inflation factors (VIF) are less than 5 .

The normality of the residual was tested with the normal P-P plot regression standardized residual. The plot indicated that there are few deviation from the line of best fit, however we concluded that the residual are normally distributed. This is confirmed by the histogram of the regression standardized residual against frequency. Therefore from the two residual plots, it was concluded that our model is fit and hence the independent variables predict the dependent variable. The appendix table $\mathrm{A}$ and $\mathrm{B}$ provide much evidence of the fitness of our model.

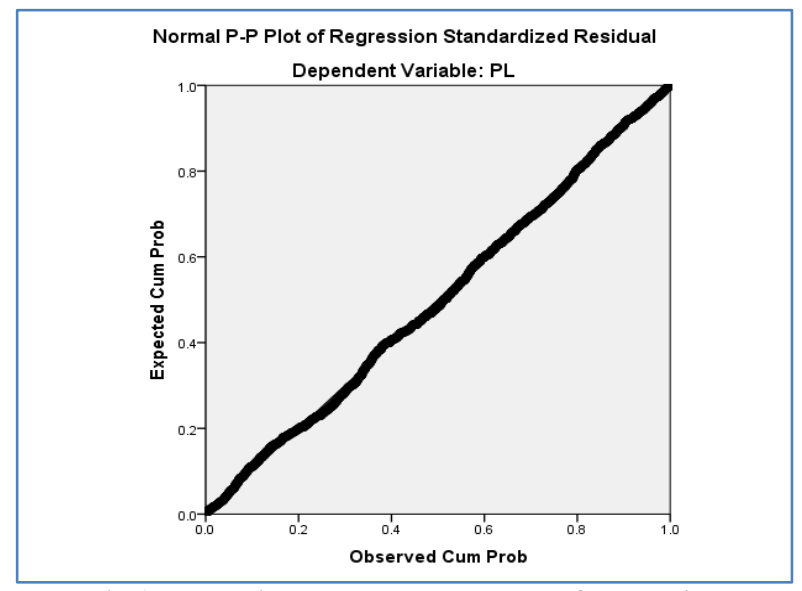

Fig-1: Normality Test: Normal P - Plot of Regression Standardized Residual

Fig-1: Shows the results of the normality test for the study. The Normal P-L plot regression standardized residual dependent variable approach was adopted.

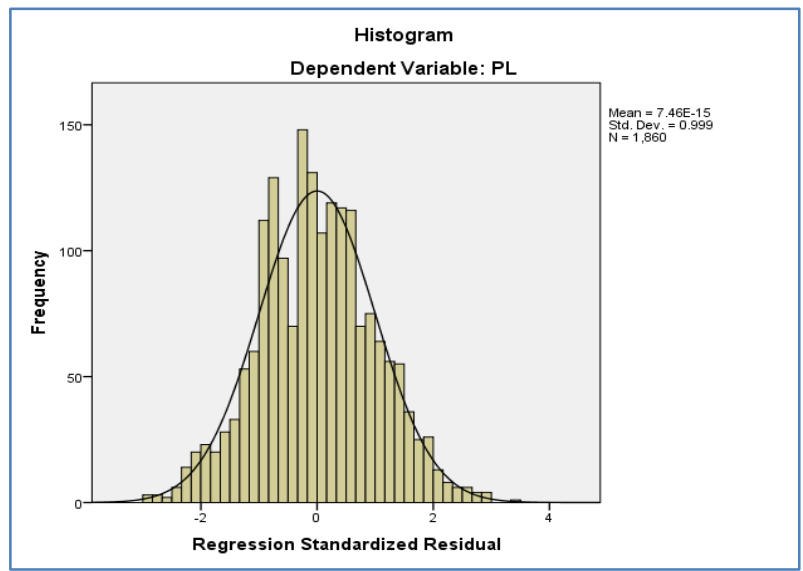

Fig-2: Histogram for normality test

Figure 2 is the histogram representation of the normality test based on the regression standardized residual.

\section{DISCUSSION OF RESULTS}

The purpose of this study was to examine the effect of the quality of doctor services on patient loyalty via the mediating influence of patient satisfaction.

The results of the study show that the quality of doctor services has a significant positive effect on patient satisfaction. This is consistent with the findings of $\mathrm{Wu}$ and $\mathrm{Lu}$ [66] who found that the quality of doctor services positively influences patient satisfaction. Jalil, Zakar [67] also confirms in their study that when doctors provide services of high quality, patients become satisfied. This result is indicative of patients making informed decision on their choice of hospitals. It is equally reflective of the need for hospitals to put in measures to ensure higher quality of doctor services to improve patronage as patients' satisfaction has been positively linked to the quality of the doctors services provided which includes doctors' availability for appointment, positive attitude towards patients, professional concern and empathy among others.

Again, the study brought to light that the quality of doctor services has a significant positive effect on patient loyalty. Gérard, François [16] in their study posited that when doctors render highly qualified services, the more loyal patients become. Loyal customers tend to exhibit two kinds of behaviors: first revisiting the same doctor and recommending the doctor to the others which helps boost the image of the 
healthcare unit. This result is consistent with the other studies $[39,49,52]$.

Further, the results show that patient satisfaction has a significant positive effect on patient loyalty. This implies that if the patient is satisfied with the services rendered by the doctor, it tends to increase their loyalty. Simply put, the satisfaction or dissatisfaction of a patient in relation to the quality of services provided by the doctor has an influence on loyalty. Studies confirm this finding [31, 68, 69].

Finally, patient satisfaction is an important mediator in the relationship between the quality of doctor services and patient loyalty. Patient satisfaction and quality of doctor services yielded positive Beta coefficients indicating that they result in patient loyalty. This finding means that the path from service quality to patient satisfaction is an important way to influence patient loyalty. Thus, quality of doctor services has a significant direct influence on patient loyalty and patient satisfaction has a significant influence on patient loyalty. In addition, this finding is consistent with previous studies, suggesting that patient satisfaction plays a key mediating role between quality of doctor services and patient loyalty [70-72].

In the quest of establishing differential effects based on demographic moderators of gender and proximity, the study assessed the within and between construct impacts. From the results of the study, gender does not influence the concept of satisfaction. This implies that being male or female does not necessarily inform the choice of hospital. Although in other studies $[64,73]$ gender was seen as a moderator, it was only in the cases of specialized hospital like gynecological hospitals. Proximity equally had no effect on satisfaction and further loyalty, implying that geographical distance to a health facility does not influence one's decision to patronize healthcare but rather the quality of care given is considered. This explains that if the a doctor or doctors in a particular healthcare unit offer services of high quality, gender and proximity has no influence because so far as the patient is highly satisfied, he or she will revisit the healthcare unit and further recommend it to others.

\section{CONCLUSION AND IMPLICATIONS}

This study explores a model that combines doctor service quality, patient satisfaction, and patient loyalty. All the five hypotheses of this study were supported which proves that the model fit was good and requires serious considerations. The competitiveness of the health sector with the proliferation of private and government owned hospitals in contemporary era has necessitated hospital administrators and managers to seek ways of remaining relevant in the competitive space. As a result, they are learning and gaining knowledge as a way to maintain a competitive advantage. Thus, the results of this study can help hospital managers and administrators better understand the interrelationship among doctor service quality, patient satisfaction and patient loyalty, as well as the mechanism for improving patient loyalty.

First, the results of the study show that service quality and patient satisfaction play an indispensable role in ensuring patient loyalty. In this case, doctor service quality is a very effective means of improving patient satisfaction, which in turn increases patient loyalty. Hospital administrators should therefore plan and implement patient-centered service strategies that are expected to lead to greater patient satisfaction and further loyalty. Patient-centered service strategies are critical to delivering a high level of care and must be carried out in a multidimensional way, including assurance, empathy, responsiveness, reliability, and tangible. With regard to assurance, it is imperative to assure patients that they will receive the level of quality of service they expect when they visit a health care unit. Doctors must demonstrate good professionalism, technical skills, efficiency and courtesy to gain the loyalty of patients and hospitals. When it comes to empathy, doctors should value the expression of soft skills, such as providing personalized attention, understanding the needs of patients, and showing care and concern. In terms of responsiveness, responding quickly to patients' requests and communicating openly with them is an essential part of health care delivery. In terms of reliability, doctors should strive to ensure the correct and reliable performance of medical services, such as availability for appointments, punctuality and follow-up of patients. Therefore, it is necessary for hospital management to examine the needs and expectations of patients and put in effective strategies to meet them to ensure the patients' satisfaction and further earn their loyalty.

Again from the results, findings and conclusion, the role of patient loyalty in further enhancing the relationship between quality of doctor service and patients satisfaction cannot be underestimated. It is therefore recommended that management should introduce policies that increase patients' loyalty like environmental cleanliness, warm receptive practices, reduction of waiting time to the barest minimum, positive patient-staff relationships and addressing patients' grievances swiftly.

\section{REFERENCES}

1. Ha, J. F., \& Longnecker, N. (2010). Doctor-patient communication: a review. Ochsner Journal, 10(1), 38-43.

2. Honavar, S. G. (2018). Patient-physician relationship-Communication is the key. Indian journal of ophthalmology, 66(11), 1527.

3. Jani, B. D., Blane, D. N., \& Mercer, S. W. (2012). The role of empathy in therapy and the physicianpatient relationship. Complementary Medicine Research, 19(5), 252-257. 
4. Thom, D. H. (2001). Physician behaviors that predict patient trust. Journal of Family Practice, 50(4), 323-323.

5. Krupat, E., Rosenkranz, S. L., Yeager, C. M., Barnard, K., Putnam, S. M., \& Inui, T. S. (2000). The practice orientations of physicians and patients: the effect of doctor-patient congruence on satisfaction. Patient education and counseling, 39(1), 49-59.

6. Hall, J. A., Horgan, T. G., Stein, T. S., \& Roter, D. L. (2002). Liking in the physician-patient relationship. Patient education and counseling, 48(1), 69-77.

7. Fuertes, J. N., Mislowack, A., Bennett, J., Paul, L., Gilbert, T. C., Fontan, G., \& Boylan, L. S. (2007). The physician-patient working alliance. Patient education and counseling, 66(1), 29-36.

8. Schneider, J., Kaplan, S. H., Greenfield, S., Li, W., \& Wilson, I. B. (2004). Better physician-patient relationships are associated with higher reported adherence to antiretroviral therapy in patients with HIV infection. Journal of general internal medicine, 19(11), 1096-1103.

9. Love, M. M., MAINOUS, A. G. I., Talbert, J. C., \& Hager, G. L. (2000). Continuity of care and the physician-patient relationship. Journal of Family Practice, 49(11), 998-998.

10. Zolnierek, K. B. H., \& DiMatteo, M. R. (2009). Physician communication and patient adherence to treatment: a meta-analysis. Medical care,47(8), 826.

11. Street, R. L., Krupat, E., Bell, R. A., Kravitz, R. L., \& Haidet, P. (2003). Beliefs about control in the physician-patient relationship. Journal of general internal medicine, 18(8), 609-616.

12. Kerse, N., Buetow, S., Mainous, A. G., Young, G., Coster, G., \& Arroll, B. (2004). Physician-patient relationship and medication compliance: a primary care investigation. The Annals of Family Medicine, 2(5), 455-461.

13. Bao, Y., Fan, G., Zou, D., Wang, T., \& Xue, D. (2017). Patient experience with outpatient encounters at public hospitals in Shanghai: examining different aspects of physician services and implications of overcrowding. PLoS One, 12(2).

14. Bertakis, K. D., \& Azari, R. (2012). Patientcentered care: the influence of patient and resident physician gender and gender concordance in primary care. Journal of Women's Health, 21(3), 326-333.

15. Chipidza, F. E., Wallwork, R. S., \& Stern, T. A. (2015). Impact of the doctor-patient relationship. The primary care companion for CNS disorders, 17(5).

16. Gérard, L., François, M., de Chefdebien, M., SaintLary, O., \& Jami, A. (2016). The patient, the doctor, and the patient's loyalty: a qualitative study in French general practice. $\mathrm{Br} J$ Gen Pract, 66(652), e810-e818.
17. Bolin, K., Lindgren, A., Lindgren, B., \& Lundborg, P. (2009). Utilisation of physician services in the 50+ population: the relative importance of individual versus institutional factors in 10 European countries. International journal of health care finance and economics, 9(1), 83.

18. Petterson, S. M., Liaw, W. R., Phillips, R. L., Rabin, D. L., Meyers, D. S., \& Bazemore, A. W. (2012). Projecting US primary care physician workforce needs: 2010-2025. The Annals of Family Medicine, 10(6), 503-509.

19. Krasner, M. S., Epstein, R. M., Beckman, H., Suchman, A. L., Chapman, B., Mooney, C. J., \& Quill, T. E. (2009). Association of an educational program in mindful communication with burnout, empathy, and attitudes among primary care physicians. Jama, 302(12), 1284-1293.

20. Surpin, J., \& Kalison, M. (2009). U.S. Patent No. 7,546,245. Washington, DC: U.S. Patent and Trademark Office.

21. Arasli, H., Ekiz, E. H., \& Katircioglu, S. T. (2008). Gearing service quality into public and private hospitals in small islands. International journal of health care quality assurance.

22. Fatima, T., Malik, S. A., \& Shabbir, A. (2018). Hospital healthcare service quality, patient satisfaction and loyalty. International Journal of Quality \& Reliability Management.

23. Farley, H., Enguidanos, E. R., Coletti, C. M., Honigman, L., Mazzeo, A., Pinson, T. B., ... \& Wiler, J. L. (2014). Patient satisfaction surveys and quality of care: an information paper. Annals of emergency medicine, 64(4), 351-357.

24. Kim, Y. K., Cho, C. H., Ahn, S. K., Goh, I. H., \& Kim, H. J. (2008). A study on medical services quality and its influence upon value of care and patient satisfaction-Focusing upon outpatients in a large-sized hospital. Total Quality Management, 19(11), 1155-1171.

25. Al-Abri, R., \& Al-Balushi, A. (2014). Patient satisfaction survey as a tool towards quality improvement. Oman medical journal, 29(1), 3.

26. Naidu, A. (2009). Factors affecting patient satisfaction and healthcare quality. International journal of health care quality assurance.

27. Lee, W. I., Chen, C. W., Chen, T. H., \& Chen, C. Y. (2010). The relationship between consumer orientation, service value, medical care service quality and patient satisfaction: The case of a medical center in Southern Taiwan. African Journal of Business Management, 4(4), 448.

28. Bjertnaes, O. A., Sjetne, I. S., \& Iversen, H. H. (2012). Overall patient satisfaction with hospitals: effects of patient-reported experiences and fulfilment of expectations. BMJ Qual Saf,21(1), 39-46.

29. Bakan, I., \& Buyukbese, A. T. (2013). The relationship between employees' income level and employee job satisfaction: An empirical 
study. International Journal of Business and Social Science, 4(7).

30. Hekkert, K. D., Cihangir, S., Kleefstra, S. M., van den Berg, B., \& Kool, R. B. (2009). Patient satisfaction revisited: a multilevel approach. Social science \& medicine, 69(1), 68-75.

31. Wu, C. C. (2011). The impact of hospital brand image on service quality, patient satisfaction and loyalty. African Journal of Business Management, 5(12), 4873.

32. East, R., Sinclair, J., \& Gendall, P. (2000). Loyalty: definition and explanation. Visionary Marketing for the 21st Century: Facing the Challenge.

33. Buttle, F., \& Burton, J. (2002). Does service failure influence customer loyalty?. Journal of Consumer Behaviour: an international research review, 1(3), 217-227.

34. Shukla, P. (2004). Effect of product usage, satisfaction and involvement on brand switching behaviour. Asia Pacific Journal of Marketing and Logistics, 16(4), 82-104.

35. Oliver, R. L. (1999). Whence consumer loyalty?. Journal of marketing, 63(4_suppl1), 3344.

36. Chang, C. W., Tseng, T. H., \& Woodside, A. G. (2013). Configural algorithms of patient satisfaction, participation in diagnostics, and treatment decisions' influences on hospital loyalty. Journal of Services Marketing.

37. Sumaedi, S., Bakti, I. G. M. Y., Rakhmawati, T., Astrini, N. J., Widianti, T., \& Yarmen, M. (2014). The empirical study on patient loyalty. Clinical Governance: An International Journal.

38. Torres, E., Vasquez-Parraga, A. Z., \& Barra, C. (2009). The path of patient loyalty and the role of doctor reputation. Health Marketing Quarterly, 26(3), 183-197.

39. Arab, M., Tabatabaei, S. G., Rashidian, A., Forushani, A. R., \& Zarei, E. (2012). The effect of service quality on patient loyalty: a study of private hospitals in Tehran, Iran. Iranian journal of public health, 41(9), 71.

40. Da Silva, R. V., \& Alwi, S. F. S. (2008). Online corporate brand image, satisfaction and loyalty. Journal of Brand Management, 16(3), 119144.

41. Zhou, W. J., Wan, Q. Q., Liu, C. Y., Feng, X. L., \& Shang, S. M. (2017). Determinants of patient loyalty to healthcare providers: An integrative review. International Journal for Quality in Health Care, 29(4), 442-449.

42. Morris, B. J., Jahangir, A. A., \& Sethi, M. K. (2013). Patient satisfaction: an emerging health policy issue. AAOS Now, 7(6), 29.

43. Andaleeb, S. S., Siddiqui, N., \& Khandakar, S. (2007). Patient satisfaction with health services in Bangladesh. Health policy and planning, 22(4), 263-273.

44. Marcinowicz, L., Chlabicz, S., \& Grebowski, R. (2009). Patient satisfaction with healthcare provided by family doctors: primary dimensions and an attempt at typology. BMC Health Services Research, 9(1), 63.

45. Sodani, P. R., Kumar, R. K., Srivastava, J., \& Sharma, L. (2010). Measuring patient satisfaction: A case study to improve quality of care at public health facilities. Indian journal of community medicine: official publication of Indian Association of Preventive \& Social Medicine, 35(1), 52.

46. Zhou, W. J., Wan, Q. Q., Liu, C. Y., Feng, X. L., \& Shang, S. M. (2017). Determinants of patient loyalty to healthcare providers: An integrative review. International Journal for Quality in Health Care, 29(4), 442-449.

47. Gaur, S. S., Xu, Y., Quazi, A., \& Nandi, S. (2011). Relational impact of service providers' interaction behavior in healthcare. Managing Service Quality: An International Journal.

48. Verkamp, J. (2013). Patient loyalty and the social media effect. The Journal of medical practice management: MPM, 29(2), 96.

49. Astuti, H. J., \& Nagase, K. (2014). Patient loyalty to healthcare organizations: Relationship marketing and satisfaction. International Journal of Management and Marketing Research, 7(2), 39-56.

50. Naik Panvelkar, P., Armour, C., \& Saini, B. (2010). Community pharmacy-based asthma serviceswhat do patients prefer?. Journal of Asthma, 47(10), 1085-1093.

51. Wang, H. L., Huang, J. Y., \& Howng, S. L. (2011). The effect on patient loyalty of service quality, patient visit experience and perceived switching costs: lessons from one Taiwan university hospital. Health services management research, 24(1), 29-36.

52. Huang, J. A., Lai, C. S., Hu, J. S., \& Weng, R. H. (2014). The impact of market orientation on patient loyalty: the mediation of relationship quality. Service Business, 8(4), 499-515.

53. Kessler, D. P., \& Mylod, D. (2011). Does patient satisfaction affect patient loyalty?. International journal of health care quality assurance.

54. Lai, F., Griffin, M., \& Babin, B. J. (2009). How quality, value, image, and satisfaction create loyalty at a Chinese telecom. Journal of business research, 62(10), 980-986.

55. Anbori, A., Ghani, S. N., Yadav, H., Daher, A. M., \& Su, T. T. (2010). Patient satisfaction and loyalty to the private hospitals in Sana'a, Yemen. International Journal for Quality in Health Care, 22(4), 310-315.

56. Platonova, E. A., Kennedy, K. N., \& Shewchuk, R. M. (2008). Understanding patient satisfaction, trust, and loyalty to primary care physicians. Medical Care Research and Review, 65(6), 696-712.

57. Hu, H. Y., Chiu, S. I., Cheng, C. C., \& Hsieh, Y. F. (2010). A study on investigating patient satisfaction of medical centers using Taiwan customer satisfaction index in Taiwan. African Journal of Business Management, 4(14), 3207. 
58. Winsted, K. F. (2000). Service behaviors that lead to satisfied customers. European Journal of Marketing.

59. Söderlund, M., \& Rosengren, S. (2008). Revisiting the smiling service worker and customer satisfaction. International Journal of Service Industry Management.

60. Raposo, M. L., Alves, H. M., \& Duarte, P. A. (2009). Dimensions of service quality and satisfaction in healthcare: a patient's satisfaction index. Service Business, 3(1), 85-100.

61. Cooper, J., \& Schindler, M. (2008). Perfect Sample Size in Research. New Jersey.

62. Babbie, E. R. (2013). The basics of social research. Cengage learning.

63. Creswell, J. W., \& Poth, C. N. (2016). Qualitative inquiry and research design: Choosing among five approaches. Sage publications.

64. Qin, G., Boonme, K., George, B., \& Prybutok, V. (2017). The moderating effect of gender in urgent care service satisfaction. Quality Management Journal, 24(3), 20-30.

65. Watson, G. S., \& Durbin, J. (1951). Exact tests of serial correlation using noncircular statistics. The Annals of Mathematical Statistics, 446-451.

66. Wu, H., \& Lu, N. (2018). Service provision, pricing, and patient satisfaction in online health communities. International journal of medical informatics, 110, 77-89.

67. Jalil, A., Zakar, R., Zakar, M. Z., \& Fischer, F. (2017). Patient satisfaction with doctor-patient interactions: a mixed methods study among diabetes mellitus patients in Pakistan. BMC health services research, 17(1), 155.

68. Lien, C. H., Wu, J. J., Chen, Y. H., \& Wang, C. J. (2014). Trust transfer and the effect of service quality on trust in the healthcare industry. Managing Service Quality.

69. Fonseca, J. R. (2013). How satisfied are Portuguese citizens with public hospitals' service?. International journal of health care quality assurance.

70. Ahmed, S., Tarique, K. M., \& Arif, I. (2017). Service quality, patient satisfaction and loyalty in the Bangladesh healthcare sector. International journal of health care quality assurance.

71. Meesala, A., \& Paul, J. (2018). Service quality, consumer satisfaction and loyalty in hospitals: Thinking for the future. Journal of Retailing and Consumer Services, 40, 261-269.

72. Fatima, T., Malik, S. A., \& Shabbir, A. (2018). Hospital healthcare service quality, patient satisfaction and loyalty. International Journal of Quality \& Reliability Management.

73. Noro, I., Roter, D. L., Kurosawa, S., Miura, Y., \& Ishizaki, M. (2018). The impact of gender on medical visit communication and patient satisfaction within the Japanese primary care context. Patient education and counseling, 101(2), 227-232.

\section{APPENDIX TABLE}

Table-A1: Collinearity Diagnostics

\begin{tabular}{|rr|r|r|r|r|r|}
\hline Model dimension & Eigenvalue & Condition index & \multicolumn{3}{|c|}{ Variance Proportions } \\
\cline { 5 - 7 } & & & & Constant & PS & DS \\
\hline \multirow{2}{*}{ model } & 1 & 2.941 & 1.000 & 0.01 & 0.00 & 0.00 \\
& 2 & 0.040 & 8.564 & 0.98 & 0.17 & 0.10 \\
& 3 & 0.019 & 12.467 & 0.01 & 0.82 & 0.90 \\
\hline
\end{tabular}

Table-A2: Residual Statistics

\begin{tabular}{|r|r|r|r|r|r|}
\hline & Minimum & Maximum & Mean & Std. Deviation & $\mathbf{N}$ \\
\hline Predicted Value & 1.1516 & 4.7059 & 3.146 & 0.756 & 2360 \\
Residual & -2.63241 & 2.69074 & 0.000 & 0.845 & 2360 \\
Std. Predicted Value & -2.639 & 2.062 & 0.000 & 1.000 & 2360 \\
Std. Residual & -3.111 & 3.180 & 0.000 & 1.000 & 2360 \\
\hline
\end{tabular}

